\title{
Experimental and Numerical Studies on Response of the Stone Column in Layered Soil
}

\author{
P. Mohanty ${ }^{1} \cdot$ M. Samanta ${ }^{1}$
}

Received: 17 March 2015/Accepted: 21 July 2015/Published online: 5 August 2015

(c) Springer International Publishing AG 2015

\begin{abstract}
This paper describes the soil layering effects on response of the stone column and stone column improved ground through a series of small scale laboratory tests and numerical analyses. Two types of layering systems, i.e. soft clay overlying stiff clay and vice versa are considered for the present study. The entire laboratory tests were carried out on $88 \mathrm{~mm}$ diameter stone columns installed in a two layered soil systems. Unit cell concept is used to idealize the behaviour of a single column within an infinite group of stone columns. Entire unit cell and only the stone column area were loaded to evaluate the stress versus settlement response of the entire improved ground and that of the stone column. Effects of the top soft and stiff clay layer thickness on the axial stress of the whole improved ground and stone column only are evaluated through laboratory tests. A detailed parametric study using finite element based software Plaxis was also carried out. Elastic-perfectly plastic Mohr-Coulomb failure criterion with drained conditions was used for the soil and stone columns in the numerical analyses. Result shows that the limiting axial stress of the stone column is found to be influenced by the top clay layer thickness up to two times the diameter of the stone column beyond which it remains constant for both the layering systems. The limiting axial stress of the whole improved ground is found to be influenced by the presence of the top layer up to a depth of four times the diameter of the stone column for both the layering systems. The stiffness improvement factor of the improved ground increases
\end{abstract}

M. Samanta

manojit_samanta@rediffmail.com

P. Mohanty

pyushmohanty@gmail.com

1 Scientist, CSIR-CBRI, Roorkee 247667, India with increase in the thickness of the top soft clay layer and attains maximum value for the full depth of soft clay whereas it remains constant for different depth of the top stiff clay. The vertical extent of the bulging increases with increase in the thickness of the top soft clay up to two times the diameter of the stone column for both the layering systems.

Keywords Stone column - Plaxis - Stiffness - Bulging · Unit cell · Layered soil

$\begin{array}{ll}\begin{array}{l}\text { Abbreviations } \\ L_{1}\end{array} & \begin{array}{l}\text { Layering system soft clay overlying } \\ \text { stiff clay (mm) }\end{array} \\ L_{2} & \begin{array}{l}\text { Layering system stiff clay overlying } \\ \text { soft clay (mm) } \\ A_{\mathrm{r}}\end{array} \\ C_{\mathrm{u}} & \begin{array}{l}\text { Area replacement ratio, dimensionless } \\ \text { Undrained shear strength (kPa) }\end{array} \\ \mathrm{SIF} & \begin{array}{l}\text { Stiffness improvement factor, } \\ \text { dimensionless }\end{array} \\ E_{\mathrm{treated}}, E_{\mathrm{untreated}} & \begin{array}{l}\text { Stiffness of treated and untreated soil } \\ \text { respectively (kPa) }\end{array} \\ T & \begin{array}{l}\text { Thickness of top soft clay (mm) } \\ \text { Diameter of stone column (mm) }\end{array} \\ D & \begin{array}{l}\text { Displacement in the lateral direction } \\ (\mathrm{mm})\end{array} \\ U_{\mathrm{x}} & \begin{array}{l}\text { Depth along length of the stone column } \\ (\mathrm{mm})\end{array} \\ Y & \end{array}$

\section{Introduction}

Due to the rapid development of infrastructures, availability of suitable construction sites is decreasing day by day. Therefore, the use of marginal sites and weak soils for 
construction of civil structures has become inevitable. Among a variety of methods used for the ground improvements, stone columns are widely used to improve the bearing capacity of the very soft/soft soils and to reduce the total and differential settlements of the super structures. Stone columns are successfully used to support the earthen embankments, LPG storage tanks, raft foundations, bridge approach fills, to increase the stability of slopes and to reduce the liquefaction potential of loose cohesionless soil [1]. Stone columns acts as an effective ground treatment method because of the three primary reasons. First, it acts as a stiffer medium and increases the load bearing capacity and stiffness of the improved ground due to its higher frictional strength than the surrounding soils. It also accelerates the rate of consolidation and reduces the post construction settlements $[29,41]$. Third, radial deformation and subsequent increase in the lateral earth pressure coefficient of the surrounding soft clay occurs during the installation of stone columns [9, 10, 12]. Therefore, in cohesive soils, the stone column method of ground improvement techniques works very efficiently when the undrained shear strength of the in situ soil is in the range of 15-35 kPa.

A number of theories have been developed to estimate the bearing capacity and settlement of the stone column reinforced ground considering the different failure mechanisms of the stone columns. Greenwood [11] estimated the ultimate bearing capacity considering that the stone column fails in bulging and its capacity is governed by the passive resistance offered by the surrounding soft soils. Vesic [39] based on the cavity expansion theory estimated the ultimate bearing capacity of the stone columns as a function of angle of internal friction and cohesion of the stone column material and the elastic material properties of the surrounding soil. Hughes and Withers [13] and Madhav et al. [24] established that the stone column fails in bulging and the ultimate capacity of the stone column is governed by the passive lateral resistance offered by the surrounding soils against bulging. Madhav and Vitkar [23] and Barksdale and Bachus [3] presented the ultimate bearing capacity equation of a multicolumn reinforced ground considering the shear failure mechanism. Bergado et al. [5] reported that the settlement of the reinforced ground does not improve much compared to the unimproved ground when centre to centre spacing between the stone columns is greater than four times of its diameter. Priebe [30] estimated the settlement improvement factor, defined as ratio of the settlement of the unimproved to improved ground of a rigid foundation supported by infinite number of stone columns as a function of area replacement ratio, angle of internal friction of the stone column material, constrained modulus of the surrounding soils and stone column. The 'unit cell' concept introduced by Baumann and Bauer [4] was used to isolate a single column within an infinite group of stone columns. Mckelvey et al. [26] carried out laboratory model tests in strain controlled manner on partially penetrating stone columns having length to diameter ratio of 6 and 10. Three failure modes of the stone columns namely bulging, bending and shearing were clearly observed during the tests. Stone columns, having length to diameter ratio $>6$, does not further increase the bearing capacity of the reinforced soil. Pulko and Majesh [31] presented a closed form solution to estimate the settlement of a rigid foundation supported by end bearing stone column considering the unit cell concept. The study shows that the settlement reduction and stress concentration factor increases with increase in the area replacement ratio and the peak shear strength of the granular material. The settlement reduction factor also increases with increase in the dilation angle of the granular materials. Castro and Sagaseta [8] presented a closed form solution of the radial consolidation considering the vertical and lateral deformations of the stone columns in elastic and elasto-plastic state. The equivalent co-efficient of consolidation of the stone column stabilized ground was found to be higher in elastic state of column deformation than plastic state and was dependent on modular ratio of the stone column and surrounding soils, friction angle and dilation of the column materials. Ambily and Gandhi [2] developed a design charts to estimate the settlement of the stone column reinforced ground through the model tests and finite element based numerical analyses using unit cell concept. McCabe et al. [25] compared the measured and predicted settlement improvement factors of the stone column improved grounds subjected to embankment and footing loading from 20 recorded case histories on soft cohesive soil. A comparison was also made based on the predicted and measured settlement improvement factors among different construction techniques of the stone columns and concluded that the dry bottom feed techniques is preferred method for the stone column construction in soft cohesive soil. Shahu and Reddy [36] studied the group behavior of the stone columns through small scale laboratory and numerical study. Result shows that the response of a group of floating stone columns depends mainly on the area replacement ratio and slenderness ratio, stress conditions of the surrounding soil and relative stiffness between the stone column and surrounding soil. Sivakumar et al. [38] investigated the pressure distribution along the length of a fully penetrating stone column through instrumented triaxial test for the consolidation and foundation loading. During the consolidation stage, due to compression of the surrounding soft clay, negative skin friction develops which results in an increased pressure distribution at the bottom third length of the column. An increase in the axial stress along the length up to five times the diameter of 
stone column due to foundation loading was observed. Black et al. [6] investigated the settlement behavior of single and small group of stone columns through model study on a specially developed triaxial cell. The influence of slenderness and area replacement ratios on the settlement performance of the stone column improved ground was investigated. The settlement inprovement factor increases with increase in the area replacement and slenderness ratio of the stone column up to $30-40 \%$ and $8-10$ respectively, beyond which these parameters have negligible influence.

The above literature review shows that the experimental, analytical and numerical study on the settlement and bearing capacity of the stone column improved soil has been investigated considering surrounding soil to be homogeneous in nature. However in reality, soils are layered with variable degree of stiffness of different layers [22]. Shivashankar et al. [37] investigated the response of the stone column in layered soil through laboratory model tests considering the unit cell concept. Stiffness of the entire stone column improved unit cell and the axial capacity of the stone column in soft clay overlying stiff clay was investigated. The response of the stone column on stiff clay overlying soft clay and the influence of different parameters like area replacement and slenderness ratios, relative stiffness of two layers on the response of stone column improved ground has not been investigated. The present study aims to investigate the response of the stone column in two layered soil system through the laboratory model study and the finite element based numerical study. Detailed experimental study considering the unit cell concept has been carried out to investigate the response of the stone column on soft clay overlying stiff clay and vice versa. A detailed parametric study has also been carried out using finite element based software package Plaxis. The influence of the top soft and stiff clay layer thickness and area replacement ratio on the axial capacity of the entire improved layered soil and stone column has been investigated. It is to be noted that the coupled modelling of the time-dependent soil behaviour is not adopted, since long term settlement is targeted here. Therefore, a drained behaviour is assumed in all the analysis. Also construction process of the stone column has not been modelled in the present analysis. Experimental procedure including material properties, preparation of the stone column and layered soil bed are described first in the paper. Material modelling and parametric study through finite element based software Plaxis has also been described. The results from the experimental and numerical study are presented in the last section. Influence of the thickness of the top soil layer of both the layering system on axial capacity of the stone column, stiffness of the whole improved ground and bulging behaviour of the stone column for different area replacement ratios has been investigated and presented. It is to be noted that the present study used the unit cell concept to isolate a single stone column from an infinite group of stone columns and its behaviour in the two layered soil system has been investigated. The study does not include the behaviour of the floating/end bearing stone columns of small group.

\section{Experimental Programme}

All the tests were carried out in a cylindrical mild steel tank of $600 \mathrm{~mm}$ in height and $185 \mathrm{~mm}$ in diameter as shown in Figs. 1 and 2. The cylindrical test tank represents the unit cell i.e. the influence area of a single stone column within an infinite group of stone columns. The diameter of the stone column was kept $88 \mathrm{~mm}$ in all the tests. The stone column was extended to the full depth of the unit cell to achieve length to diameter ratio $>4.5$, which is essential to develop the full axial stress in the stone column [28]. Diameter of the stone column in the unit cell represents an area replacement ratio of $22 \%$ in an equilateral triangular arrangement. An area replacement ratio of $22 \%$ was chosen for the present study because an area replacement ratio less than $10 \%$ does not show any significant improvement and greater than $35-40 \%$ is not economical [3]. A two layered soil systems, soft clay overlying stiff clay and vice versa were taken for the present investigations. The thickness of the top soft and stiff clay layers were varied to see its effects on the response of the stone column and the whole improved ground. Two types of loading, the whole unit cell area was loaded to estimate the load-settlement characteristics and stiffness of the whole improved layered soil and the stone column area alone was loaded to evaluate the axial capacity of the stone column in the layered soil. All the tests were carried out in stress controlled manner. Table 1 provides layering systems, types and numbers of tests performed in the present study. The load was applied through a hydraulic jack of 10 ton capacity and was measured with the help of duly calibrated proving ring and the corresponding settlements were

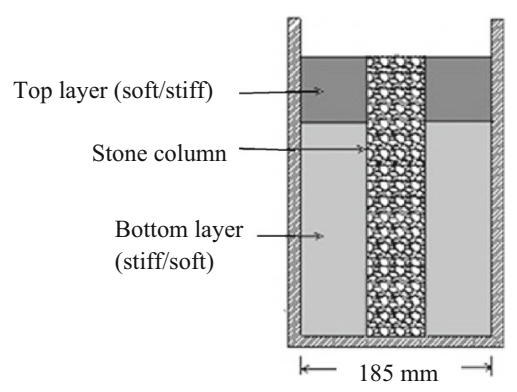

Fig. 1 Schematic diagram of model test setup 


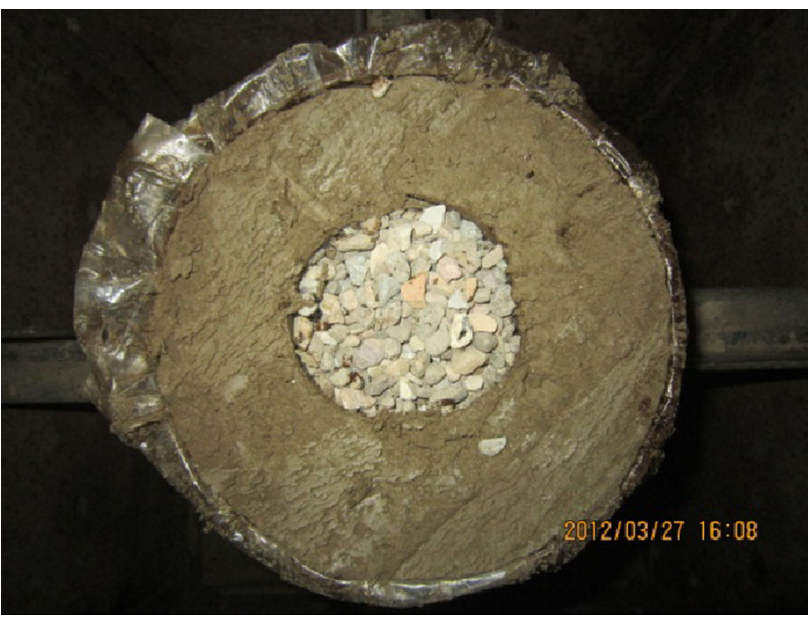

Fig. 2 Unit cell with stone column

measured through the dial gauges having least count of $0.01 \mathrm{~mm}$.

\section{Material Properties}

Clay, stones and sand are used for the preparation of clay bed, stone column and sand blanket. Laboratory tests were carried out to determine the relevant properties of these materials. The properties of these materials are given below.

\section{Stones}

Crushed stone aggregates of size $10-1.18 \mathrm{~mm}$ were used to form the stone column. The grain size distribution of the stone aggregates is shown in Fig. 3. The mixture of the stone aggregates is classified as poorly graded gravel or GP as per IS classification. The maximum $\left(\gamma_{\max }\right)$ and minimum $\left(\gamma_{\min }\right)$ dry density of the stone aggregates are 17.1 and 14.9 $\mathrm{kN} / \mathrm{m}^{3}$ respectively. Angle of internal friction of the stone aggregates was determined by carrying out a series of direct shear tests at a relative density of $60 \%$ on a box of size $300 \times 300 \times 200 \mathrm{~mm}$. The stone aggregates were sheared in a direct shear box at a constant rate of $1.25 \mathrm{~mm} /$ min under the normal pressure of 100, 150, 200 and $300 \mathrm{kPa}$ to determine its angle of internal friction.

\section{Sand}

Clean river sand used in the present study was collected from the nearby sites. The grain size distribution curve of the sand is presented in Fig. 3. The maximum and minimum dry density of sand are 17.2 and $14.6 \mathrm{kN} / \mathrm{m}^{3}$ respectively. The angle of internal friction and modulus of elasticity of the sand were determined by carrying out a series of drained triaxial tests.

\section{Clay}

The finer soil used for the present study was excavated and collected locally. It was sieved through a $0.75 \mathrm{~mm}$ sieve to remove the coarser fractions. After removing the coarser fraction, the wet sedimentation analysis was carried out to determine its grain size distribution. The particle size distribution curve is shown in Fig. 3. Other properties are: specific gravity $=2.7$, liquid limit $=42 \%$, plastic limit $=31 \%$, optimum moisture content $=21 \%$ and maximum dry density $=16.6 \mathrm{kN} / \mathrm{m}^{3}$. The soil sample is classified as CI-MI according to IS classification system. The unconfined compressive strength tests were carried out by preparing the sample on standard proctor compaction energy with different water contents. The amount of water content was varied to produce the clay samples with different consistencies, evaluated through unconfined compressive strength tests. Based on the test results, the water content and corresponding undrained shear strength values are plotted in Fig. 4. All the model tests were performed with the clay samples having two different consistencies. The required amount of water was added to the dry clay samples and compacted in standard proctor energy to obtain the desired undrained shear strength. Based on the UCS test results, water content of 27 and $35 \%$ were selected to achieve the required undrained shear strength of

Table 1 Experimental program

\begin{tabular}{|c|c|c|c|c|c|}
\hline \multirow[t]{3}{*}{ Layering system } & & \multirow{3}{*}{$\begin{array}{l}\text { Thickness } \\
\text { of top soft } \\
\text { and stiff clay }\end{array}$} & \multicolumn{3}{|c|}{ Loading Condition } \\
\hline & & & \multicolumn{2}{|c|}{ Entire area loaded } & \multirow{2}{*}{$\begin{array}{l}\text { Stone column } \\
\text { alone loaded } \\
\text { Treated soil }\end{array}$} \\
\hline & & & Untreated soil & Treated soil & \\
\hline \multirow{5}{*}{$\begin{array}{l}\text { (i) Soft clay overlying } \\
\text { stiff clay }\left(L_{1}\right) \\
\text { (ii) Stiff lay overlying } \\
\text { soft clay }\left(L_{2}\right)\end{array}$} & \multirow{5}{*}{$\begin{array}{l}\text { Area replacement } \\
\text { ratio, } A_{\mathrm{r}}=22 \%\end{array}$} & $1 d$ & $\checkmark$ & $\checkmark$ & $\checkmark$ \\
\hline & & $2 d$ & $\checkmark$ & $\checkmark$ & $\checkmark$ \\
\hline & & $3 d$ & $\nu$ & $\checkmark$ & $\checkmark$ \\
\hline & & $4 d$ & $\checkmark$ & $\checkmark$ & $\checkmark$ \\
\hline & & Homogeneous & $\nu$ & $\checkmark$ & $\checkmark$ \\
\hline
\end{tabular}




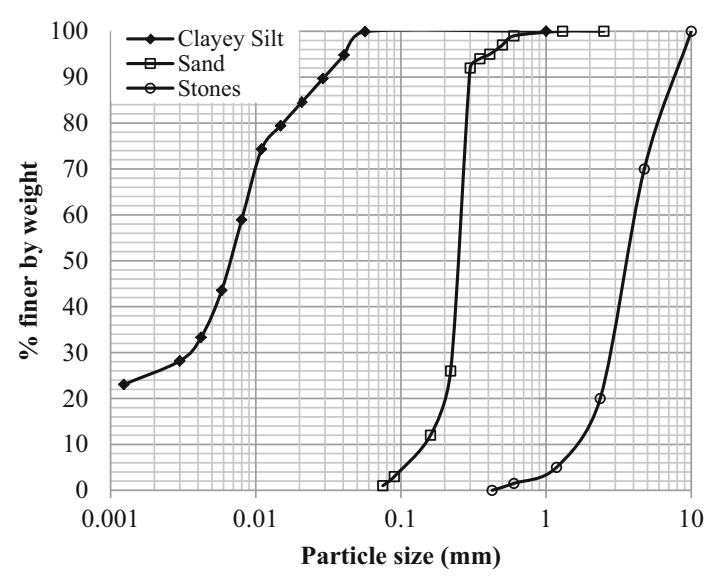

Fig. 3 Grain size distribution curve for clay, sand and stone

54 and $15 \mathrm{kPa}$ representing the stiff and soft clay respectively [33]. Modulus of elasticity of the soft and stiff clay used in the numerical analysis was determined from the consolidation tests. Modulus of elasticity of the clay is inverse of the coefficient of volume compressibility obtained from the consolidation test corresponding to a pressure range of 100-200 kPa. The confinement offered by the surrounding columns justify the use of constrained modulus values obtained from the consolidation tests as all the tests are intended to predict the behavior of interior stone columns in a group [2].

\section{Preparation of Layered Clay Stratums}

For preparation of each test bed, the pulverized clay was oven dried for $24 \mathrm{~h}$ and the required amount of water was added to it. The soil sample was mixed thoroughly to form a uniform paste. Two different water content as determined from the UCS test were used to create the stiff and soft clay. Before filling the soil, a thin coat of grease and polythene sheet were applied along the inner surface of the

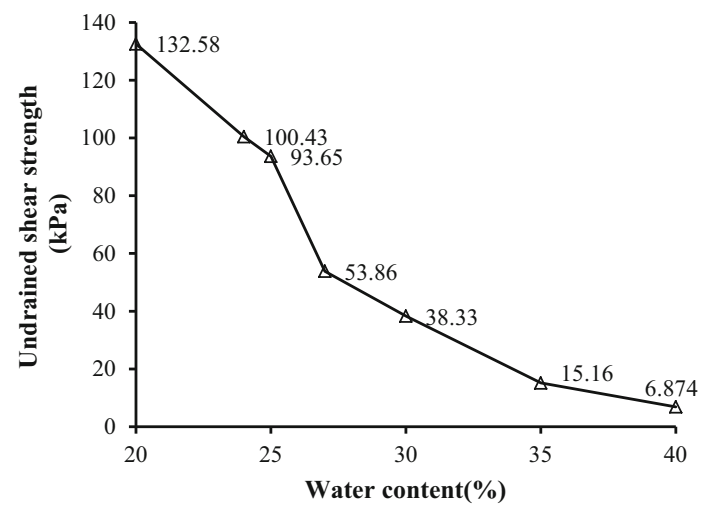

Fig. 4 Variation of undrained shear strength with moisture content unit cell tank. Grease and polythene sheets were applied to simulate the zero shear stress at the boundary of the unit cell in loaded condition [4]. The stiff clay layer was filled at the bottom of the unit cell tank up to a fixed height and followed by the soft clay stratum and vice versa to create two different layering systems. The clay soil was filled in the test tank in five equal layers and each layer was properly compacted with a hammer of $0.045 \mathrm{kN}$ to achieve a compacted height of $120 \mathrm{~mm}$. After compaction of each layer, representative clay sample was taken out for the UCS test to check its undrained shear strength. The density as determined through the standard proctor compaction tests in the laboratory was maintained in each layer for both the stiff and soft clay. Special care was also taken to ensure that no air voids are left in the prepared soil stratum. The layering systems, soft clay overlying stiff clay and stiff clay overlying soft clay are referred to as $L_{1}$ and $L_{2}$ respectively in the subsequent sections.

\section{Construction of Stone Column}

Replacement technique was used to construct the stone column for the present study. Though the other methods like forced intrusion, displacement and frozen techniques of the stone column formation are more representative of the field situations but these are difficult to implement in a small scale model and the replacement method is proved to produce the stone columns of excellent consistency [6]. A thin seamless steel pipe of $88 \mathrm{~mm}$ inner diameter and $2 \mathrm{~mm}$ wall thickness was pushed into the clay soil with the help of a hydraulic jack to construct the stone column within the unit cell. The clay inside the pipe was scooped out using a helical auger of $65 \mathrm{~mm}$ diameter. The borehole thus formed was filled with the stone aggregates in five equal lifts. The stones were compacted at a relative density of $60 \%$ within the stone column. The compaction of the stone aggregates were done by a $0.045 \mathrm{kN}$ hammer. The trial compactions were carried out using a hammer to calibrate the numbers and height of fall to get the required compacted density of the stone aggregates. The quantity of stones required in a single stage was estimated and subsequently poured in the bore hole and compacted to the desired density. The pipe was then slowly lifted up ensuring a minimum penetration depth of $20 \mathrm{~mm}$ below the top level of compacted stone aggregates to prevent caving of the clay from surrounding into the hole. Special care was taken during the construction to maintain a uniform diameter along the length of the stone column. The above mentioned procedure was repeated to complete the column up to the full height. When the entire area of the unit cell was loaded, sand blanket of $20 \mathrm{~mm}$ thickness at required density, constructed through compaction technique was placed on the top of the clay layer. 


\section{Test Procedure}

The entire testing process consists of three phases. The first phase consists of preparation of the layered clay bed and installation of the stone column. The second phase consists of application of load on the entire unit cell and the stone column area alone. In the third phase, the load and the corresponding settlement were measured with the help of calibrated dial gauges and proving ring to evaluate the axial stress versus settlement characteristics of the entire improved ground and the stone column separately. The load-settlement behavior of the stone column and the entire improved unit cell was studied by applying the vertical load from the hydraulic jack supported by a loading frame. The load on the entire unit cell area was applied through a $5 \mathrm{~mm}$ thick steel plate having diameter $5 \mathrm{~mm}$ less than the inside diameter of the unit cell. A sand blanket of $20 \mathrm{~mm}$ thickness was placed at a relative density of $80 \%$ on the top of clay bed before the entire unit cell area was loaded. The role of the top sand blanket is to distribute the load uniformly and also to serve as a horizontal drain [14]. All readings of the proving rings and dial gauges were taken manually. A constant load of $0.057 \mathrm{kN}$ was applied in each successive loading stage. It was observed from the Casagrande's Logarithmic Time Fitting method that the soil sample almost reaches $90 \%$ of the total consolidation in 2-2.5 $\mathrm{h}$ under this load. Therefore, each successive load was constantly maintained for a minimum period of $2.5 \mathrm{~h}$. The settlement was assumed to cease when the dial gauges moves less than $0.001 \mathrm{~mm} / \mathrm{min}$. A steel plate of $88 \mathrm{~mm}$ diameter and $5 \mathrm{~mm}$ thickness was used to apply the load on the area of the column alone. The load was applied up to the failure of the stone column. After the failure of the column, cement slurry was poured on top of the stone column and left undisturbed for 2 days to investigate the failure shape of the stone columns. As the cement slurry was too viscous to penetrate into highly impermeable clay area, it forms into a thick paste around the stone column area only. The clay soil surrounding the stone column was carefully extracted to examine the shape of the failed stone columns once the cement slurry get hardened.

\section{Parametric Study}

Finite element based package Plaxis has been used for the present numerical analyses. All the numerical analyses has been carried out considering the unit cell geometry in triangular arrangement of the stone columns. The numerical model has been validated with the published data of model load tests on the stone columns. The details of the numerical model, validation, material properties and parametric studies are presented in the following sections.

\section{Validation}

Results of the model load tests on stone columns area only reported by Ambily and Gandhi [2] has been used for validation purpose in the present numerical model. A $100 \mathrm{~mm}$ diameter stone column in homogeneous soft clay in the unit cell tank of $500 \mathrm{~mm}$ in height and $210 \mathrm{~mm}$ in diameter was used in the model test. The centre-to-centre spacing was kept two times the diameter of the stone column in triangular pattern arrangement and the same has been modelled in Plaxis for the validation purpose. The material properties, reported in the paper and subsequently used in the analysis has been presented in Table 2. Fifteennoded triangular elements has been used for discretization of the soil and stone column. Axisymmetric analysis has been carried out using elastic-perfectly plastic MohrCoulomb failure criterion for the soft clay, stones and sand. A drained behavior has been assumed for all the materials. Figure 5 shows the comparison of the load-settlement behaviour between the model test and the present numerical analysis. A close match is observed between the present numerical study and model test results.

\section{Material Modelling}

Axisymmetric analyses has been carried out using the elastic-perfectly plastic Mohr-Coulomb failure criterion for soft clay, stiff clay, stone and sand. All the analyses has been carried out in the drained condition. The gravity loading has been considered to generate the initial stress conditions. The construction process of the stone column and thus the stress generated due to it has not been modelled in the present analysis. Fifteen nodded triangular elements having three translational degrees of freedom per node have been used to discretise the stone column and the surrounding soil. Young's modulus, angle of internal friction and cohesion of all the materials has been determined from the relevant laboratory tests. Dilation angles have been determined from the relationship $\Psi=\phi-30^{\circ}$ and the value of poisson ratio of the corresponding soil taken from Bowels [7]. The input parameters $\left(E, C_{\mathrm{u}}, \phi, \gamma_{\mathrm{dry}}, \Psi\right)$ are given in Table 3. Figure 6 shows a typical finite element mesh used for the simulation

Table 2 Properties of the material (Ambily and Gandhi, [2])

\begin{tabular}{lll}
\hline Properties & Materials & \\
\cline { 2 - 3 } & Clay & Stone \\
\hline Modulus of elasticity $(\mathrm{kPa})$ & 5500 & 55,000 \\
Poisson's ratio $(\mu)$ & 0.42 & 0.3 \\
Shear strength $(\mathrm{kPa})$ & 30 & 0 \\
Angle of internal friction $(\varnothing)$ & 0 & $38^{\circ}$ \\
Dilatancy angle $(\Psi)$ & 0 & $4^{\circ}$ \\
\hline
\end{tabular}




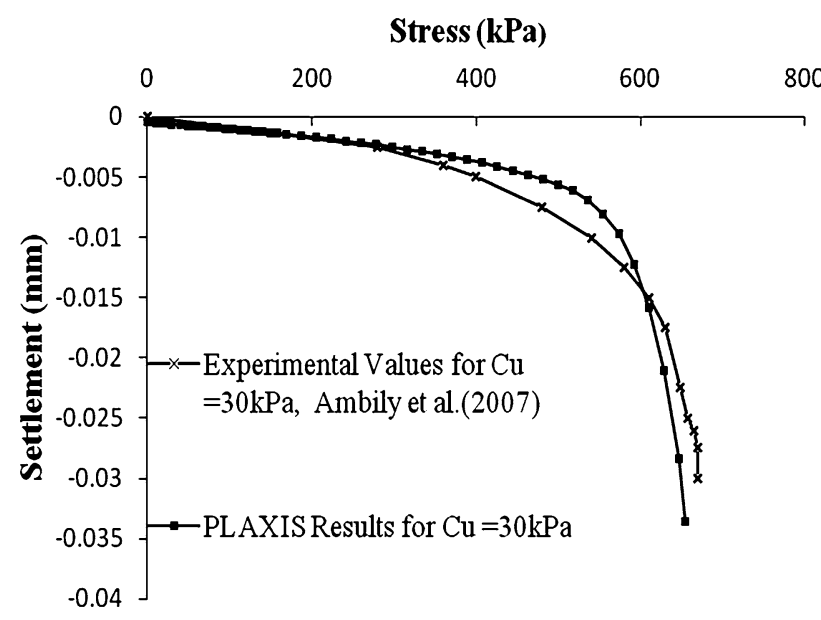

Fig. 5 Load versus settlement curve of stone column in clayey soil

of the stone column in the present numerical analysis. The mesh convergence study reveals that increasing the number of elements beyond 500 does not have any effect on the settlement response of the geometry under consideration. Subsequently 500-550 numbers of elements with the average element size of $11 \times 10^{-3} \mathrm{~m}$ or less has been used in all the numerical analysis. In the numerical model, all the nodes along the lateral periphery of the tank are restrained from moving in radial directions and all the nodes in the bottom surface of the tank are restrained to move in both radial and vertical directions. The top surface is free to move in any directions. The prescribed displacements available in Plaxis library has been applied in all the numerical analyses. The interface elements between the stone column and the surrounding soil has not been modelled in the present analysis since the stone column fails due to bulging and there is no possibility of generation of shear stresses at the interface of the stone column and soil [27, 34].

\section{Results and Discussions}

Detailed parametric study considering different parameters influencing the behaviour of the stone column and the whole improved layered soil has been carried out in the

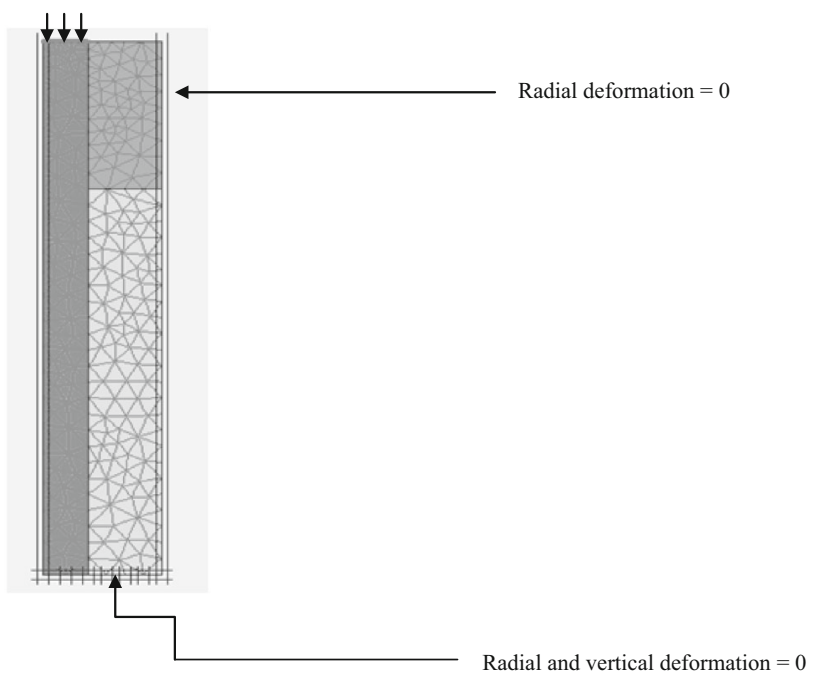

Fig. 6 Finite element mesh and boundary conditions

present study. Effects of changing the top soft and stiff clay layer thickness and the area replacement ratio on the limiting axial stress of the stone column and whole improved layered soil has been investigated in the present numerical analysis. The area replacement ratio of the stone columns has been varied from 15 to $30 \%$ for different layered soils. The axial stresses have been evaluated corresponding to various settlement level of 5-25 mm. When the entire area is loaded, because of the confinement from the boundary of the unit cell, failure does not occur and therefore the stress acting on the top surface of the whole unit cell corresponding to $20 \mathrm{~mm}$ settlement has been taken as limiting axial stress of the whole unimproved and improved soil. Axial stress on the whole unimproved soil corresponding to different level of settlement values vis-a-vis experimental and numerical results has been summarized in Table 4 . The load-settlement characteristics of the whole improved layered soil corresponding to an area replacement ratio of $22 \%$ are presented in Fig. 7. Table 4 and Fig. 7 shows a close match of the axial stress between the experimental and numerical results for unimproved and improved layered soil. Stiffness of the stone column improved layered soil, change in the limiting axial stress of the column,
Table 3 Properties of the material used in the present study

\begin{tabular}{lllll}
\hline Properties & Materials & & & \\
\cline { 2 - 5 } & Soft clay & Stiff clay & Stone & Sand \\
\hline Modulus of elasticity $(\mathrm{kPa})$ & 1100 & 6000 & 50,000 & 24,880 \\
Poisson's ratio $(\mu)$ & 0.42 & 0.35 & 0.3 & 0.3 \\
Shear strength $(\mathrm{kPa})$ & 15 & 53 & 0 & 0 \\
Angle of internal friction $(\varnothing)$ & 0 & 0 & 42 & 41 \\
Dilatancy angle $(\Psi)$ & 0 & 0 & 12 & 11 \\
$\gamma_{\text {bulk }}\left(\mathrm{kN} / \mathrm{m}^{3}\right)$ & 18.4 & 19.6 & 16.2 & 16.7 \\
\hline
\end{tabular}


extent of bulging of the stone column and the depth of maximum bulging have been investigated and presented in the following subsections.

\section{Effect of Area Replacement Ratios}

The area replacement ratio is one of the most significant parameters controlling the response of the stone column improved soil. Effects of the area replacement ratios on different parameters of the stone column improved layered soil have been investigated and presented in the following sub-sections.

\section{Limiting Axial Stress of Improved Soil}

Figure $8 \mathrm{a}, \mathrm{b}$ shows the variation of the limiting axial stress of the whole improved layered soil for different top soft and stiff clay layer thickness. A close match is observed between the experimental and numerical results for both the layering system for an area replacement ratio of $22 \%$. The limiting axial stress of the whole improved ground increases with increase in the area replacement ratio of the stone column for a fixed top soil layer thickness for both the layering systems. The area of the stone column in a given unit cell increases with increasing the area replacement ratio. As the stone column possess higher stiffness than surrounding soil, the composite stiffness and load carrying capacity of the whole improved unit cell increases with increasing the area replacement ratios. The limiting axial stress of the entire improved soil decreases as the top soft clay layer thickness increases. The extreme right points in each curve of Fig. 8a, b represent the limiting axial stress of the homogenous improved soil corresponding to the full depth of either soft or stiff clay. The limiting axial stress of the improved layered soil is significantly influenced by the presence of the top soft clay layer for layering system $L_{1}$. For example, the limiting axial stress of the entire improved layered soil is found to be higher by $140 \%$ as compared to the entire improved homogeneous soft clay

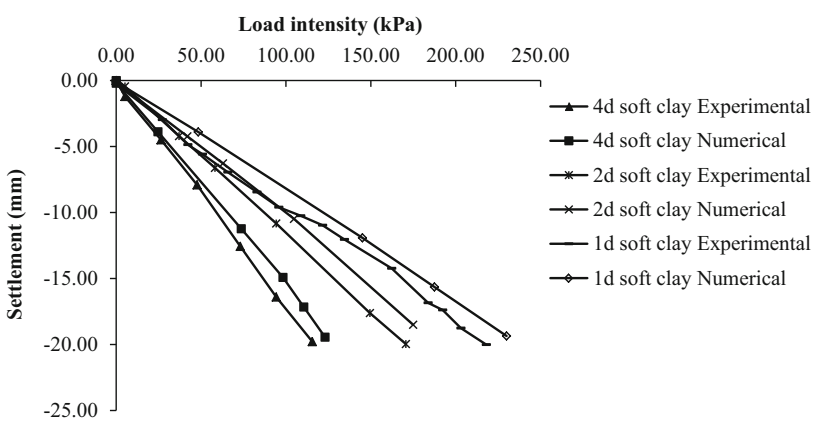

Fig. 7 Load versus settlement curve of treated soil for entire unit cell area loading $\left(L_{1}\right)$

for an area replacement ratio of $30 \%$ when top soft clay layer thickness is one times the diameter of the stone column. It can be observed from the figures that the limiting axial stress of the improved layered soil is affected by the presence of the top soft clay layer thickness up to four times the diameter of the stone column. For the top soft clay thickness more than four times the diameter of the stone column, the underlying stiff clay does not contribute in improving the limiting axial stress of the entire improved soil significantly. Therefore, the limiting axial stress of the entire improved unit cell may be taken equal to the full depth of the soft clay for layered soil having top soft clay layer thickness more than four times the diameter of the stone column. For layering system $L_{2}$, the limiting axial stress increases with increase in the top stiff clay layer thickness. When whole unit cell area is loaded, the total stress is shared by the stone column and the surrounding soil of the unit cell. The contribution of the bottom stiff clay on the axial stress decreases with increase in the top soft clay layer thickness, resulting in reduction in the limiting axial stress of the improved layered soil. For $L_{2}$ layering system, axial capacity of the surrounding soil increases with increase in the thickness of the top stiff clay which results an increase in the limiting axial capacity of the improved layered soil.

Table 4 Axial stress of untreated clay soil

\begin{tabular}{|c|c|c|c|c|c|c|c|c|c|c|}
\hline \multicolumn{11}{|l|}{ Axial stress $(\mathrm{kPa})$} \\
\hline \multirow[t]{2}{*}{ Settlement (mm) } & \multicolumn{2}{|c|}{ Homogeneous soft clay } & \multicolumn{2}{|c|}{$4 \mathrm{~d}$ Soft clay on top } & \multicolumn{2}{|c|}{ 3d Soft clay on top } & \multicolumn{2}{|c|}{ 2d Soft clay on top } & \multicolumn{2}{|c|}{ 1d Soft clay on top } \\
\hline & FEM & Exp. & FEM & Exp. & FEM & Exp. & FEM & Exp. & FEM & Exp. \\
\hline 5 & 21.4 & 23.00 & 32.03 & 29.56 & 39.07 & 35.32 & 49.0 & 44.00 & 60.1 & 55.0 \\
\hline 10 & 44.2 & 45.00 & 65.44 & 61.23 & 78.5 & 71.67 & 103.1 & 98.21 & 120.8 & 112.5 \\
\hline 15 & 66.99 & 66.03 & 101 & 93.31 & 113.5 & 105 & 144.3 & 136.2 & 180.2 & 169.6 \\
\hline 20 & 89.60 & 97.30 & 124 & 115.9 & 146.2 & 142.3 & 175.0 & 164.3 & 232.0 & 224.2 \\
\hline
\end{tabular}



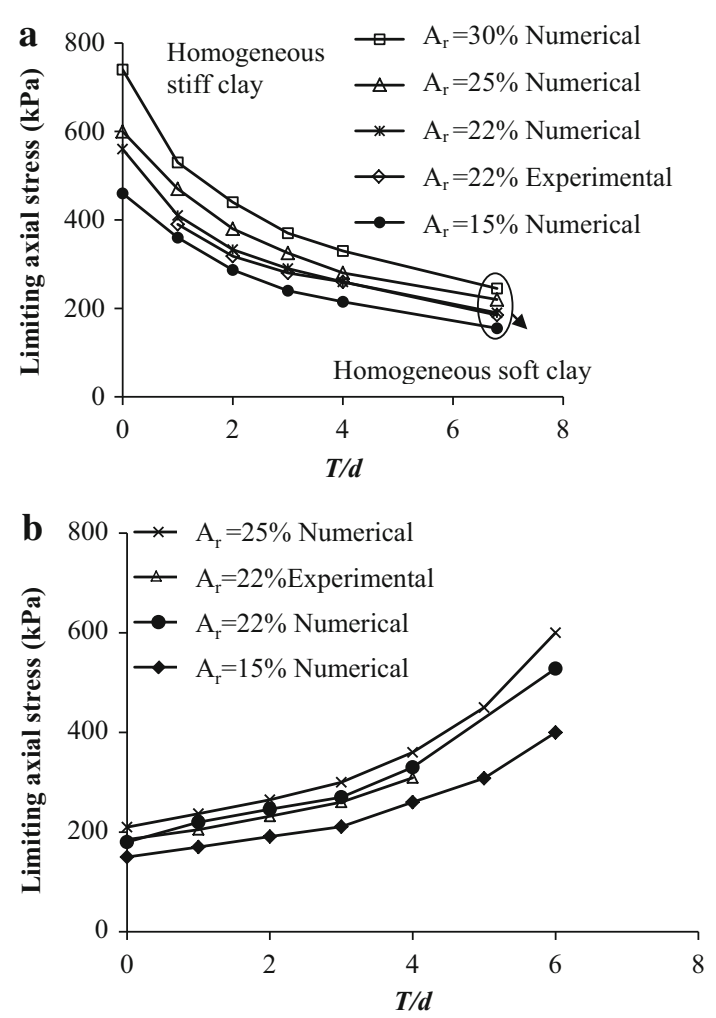

Fig. 8 a Limiting axial stress versus top soil thickness for entire unit cell area loading $\left(L_{1}\right)$. b Limiting axial stress versus top soil thickness for entire unit cell area loading $\left(L_{2}\right)$

\section{Stiffness of Improved Soil}

The settlement of a ground under the applied load is inversely proportional to the stiffness of the ground. So, the stiffness of the entire improved ground is of particular interest to estimate the settlement of the improved ground. Also to highlight the efficacy of the stone column improvement, the stiffness of the improved ground is expressed with respect to stiffness of the unimproved ground. The load-settlement graphs are linear when the entire unit cell area is loaded as shown in Fig. 7. So, the stiffness of the improved and unimproved layered soil can be calculated from the average slope of the individual plots corresponding to the different layering systems. The effect of top soft and stiff soil layer thickness on the stiffness of the improved ground has been evaluated in terms of stiffness improvement factor (SIF) and is expressed as follows.

$\mathrm{SIF}=($ Eimproved - Euimproved $) /$ Eunimproved $\times 100$

The stiffness of the improved and unimproved layered soil has been calculated from the corresponding linear load-settlement plots of different layering system for the whole unit cell area loading case. Figure 9a, b shows the effects of top layer thickness on the stiffness improvement factor of the improved layered soil for $L_{1}$ and $L_{2}$ layering system respectively. The results show that the stone column method of ground improvement technique is effective to reduce the settlement as the stiffness improvement factor is positive for both the layering systems. The increase in the stiffness improvement factor with increase in the area replacement ratio for both the layering system also indicates that the effectiveness of the stone column to reduce the settlement also increases with increase in the area replacement ratio. The stiffness improvement factor increases with increasing the thickness of the top soft clay and attains maximum for the entire depth of soft clay for $L_{1}$ layering system. The above results shows that the beneficial effects of stone column techniques is maximum when the entire depth is soft clay as stiffness improvement factor is maximum in this case. For $L_{2}$ layering system, the stiffness improvement factor remains constant for different depth of top stiff clay. Figure 10a, b shows the comparison of the stiffness improvement factors for different area replacement ratios from the present study and other published results with $L_{1}$ and $L_{2}$ layering system respectively. Figure 10a shows the stiffness improvement factor from the present study matches well with the results of Priebe [30] and Castro and Sagaseta [8] for the full depth soft clay and is higher than Pulko et al. [32]. For different thickness of the top soft soil, the stiffness improvement factor from the present study lies in between Priebe [30], Castro and Sagaseta [8] and Pulko et al. [32]. Figure 10b shows the stiffness improvement factor from the present study matches well with the results of Priebe [30] and Castro and Sagaseta [8]. Pulko et al. [32] underestimate the stiffness improvement factor when compared with the present study for $L_{2}$ layering system.

\section{Limiting Axial Stress of Stone Column}

As the stone column improved ground derives its strength from the limiting axial stress of the surrounding soil as well as that of the stone column, the study of the later is required. Figure 11a, b shows the load-settlement behaviour of the stone column for $L_{1}$ and $L_{2}$ layering system respectively. The load-settlement behaviour has been obtained by loading the stone column area only. The limiting axial stress of the stone column has been determined for each type of layered soil using the double tangent method corresponding to its load-settlement curve. Figure $11 \mathrm{a}, \mathrm{b}$ shows the variation in the limiting axial stress of the stone column for different area replacement ratios for $L_{1}$ and $L_{2}$ layering system respectively. The limiting axial stress of the stone column increases with the increase in area replacement ratio for both the layering systems. The limiting axial stress of the stone column decreases with increase in the thickness of top soft clay up to two times the 

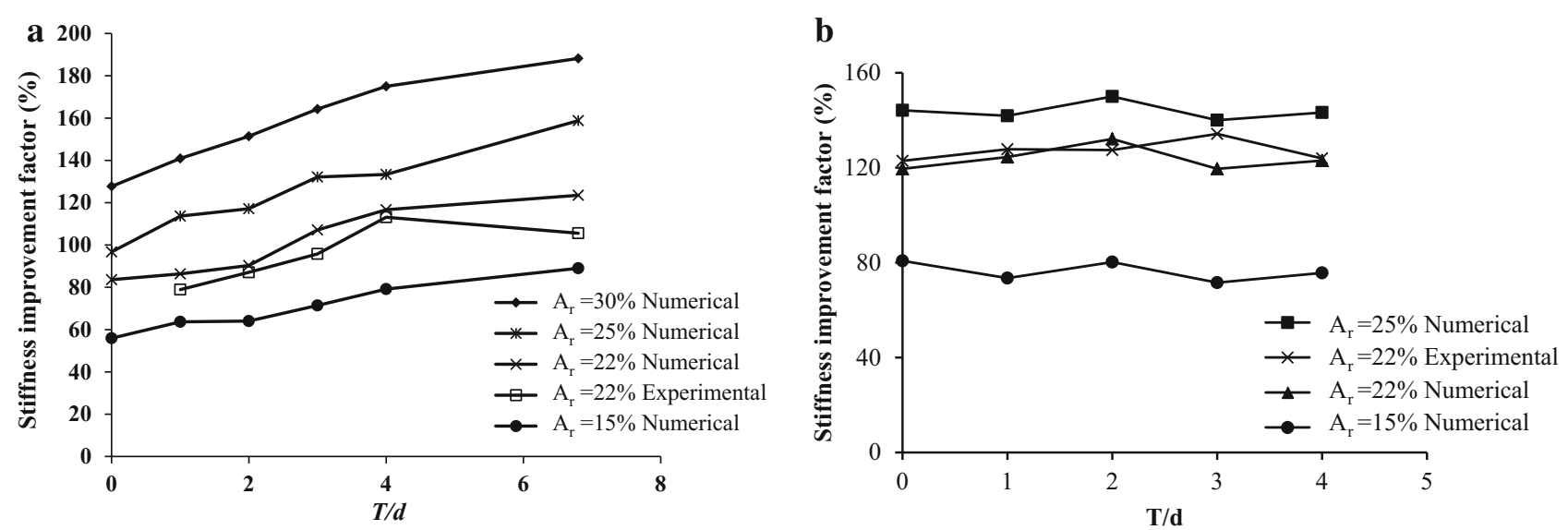

Fig. 9 a Effect of area replacement ratio on stiffness improvement factor for entire unit cell area loading $\left(L_{1}\right)$. b Effect of area replacement ratio on stiffness improvement factor for entire unit cell area loading $\left(L_{2}\right)$
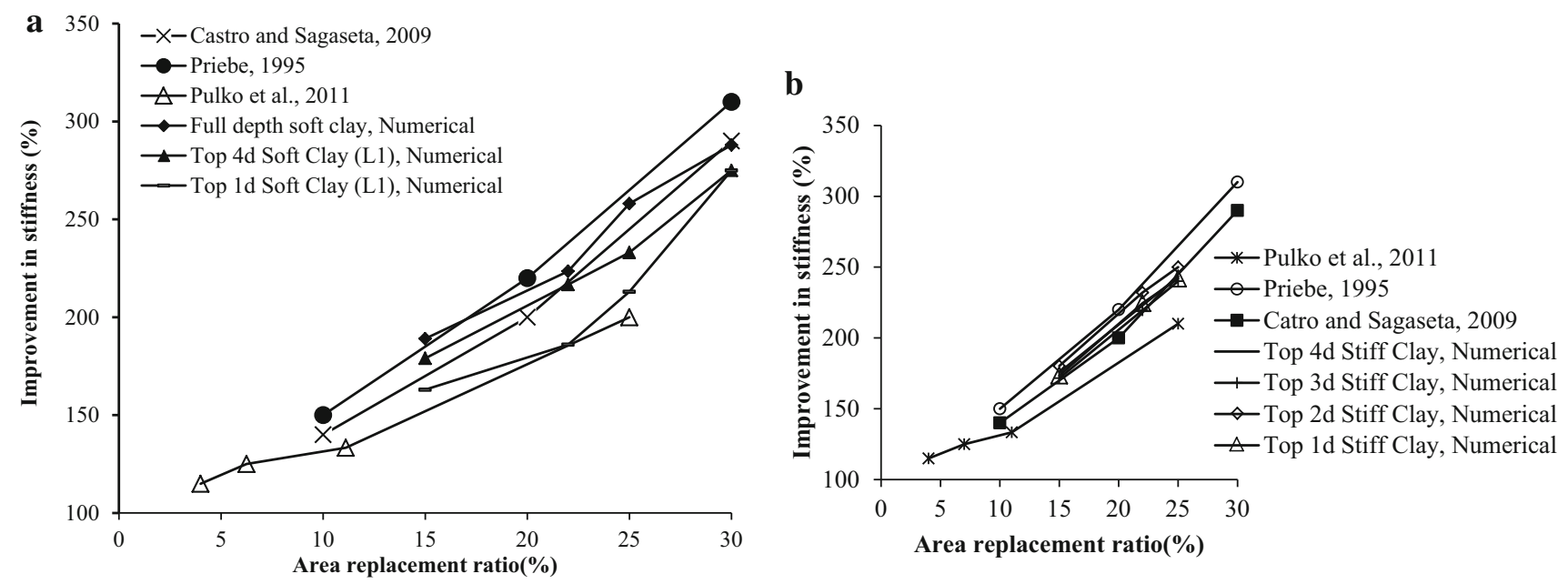

Fig. 10 a Variation of stiffness improvement factor with area replacement ratio for entire unit cell area loading $\left(L_{1}\right)$. b Variation of stiffness improvement factor with area replacement ratio for entire unit cell area loading $\left(L_{2}\right)$

diameter of the stone column beyond which it almost remains constant and equals to the limiting axial stress of the corresponding homogenous soft clay. For top soft clay thickness more than $2 \mathrm{~d}$, the effect of the bottom stiff layer on the limiting axial stress on the stone column diminishes. Figure $11 \mathrm{~b}$ shows that the limiting axial stress of the stone column increases with increase in the top stiff clay thickness up to two times the diameter of the stone column beyond which it remains constant for different area replacement ratios. The stone columns mainly derive its capacity from the resistance offered by the surrounding soils against its bulging in the upper portion. As the bulging mostly happen in the upper portions, the limiting axial stress of the stone column remain unchanged when the thickness of the top soil thickness changes from two times the diameter of stone column for both the layering system.

\section{Bulging of Stone Column}

Figure 12a, b shows the bulging of the stone column for $L_{1}$ and $L_{2}$ layering systems respectively. The bulging of the stone column occurs when only the stone column area is loaded. The bulging shown in figures is the lateral displacement at the interface of the stone column and surrounding soil for an area replacement ratio and settlement of $15 \%$ and $25 \mathrm{~mm}$ respectively. For $L_{1}$ and $L_{2}$ layering systems respectively, the horizontal extent of bulging decreases as the thickness of top clay layer increases. The horizontal extent of bulging of the stone column is more for layered soil than homogeneous soft soil. The vertical extent of bulging denotes the depth of bulge zone from top of the stone column. When the surrounding soil has only top $1 \mathrm{~d}$ soft clay, the bulging is limited in top $1 \mathrm{~d}$ portion. As the 

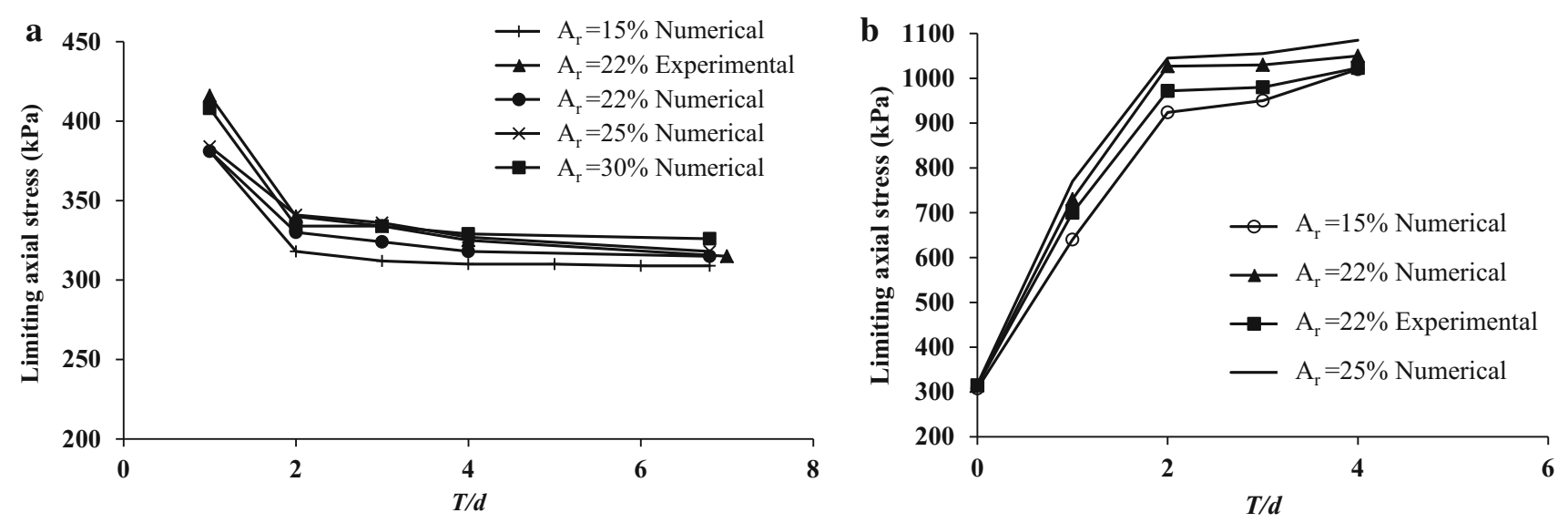

Fig. 11 a Limiting axial stress of stone column versus top clay thickness for only stone column loading $\left(L_{1}\right)$. b Limiting axial stress of stone column versus top stiff clay thickness for only stone column loading $\left(L_{2}\right)$
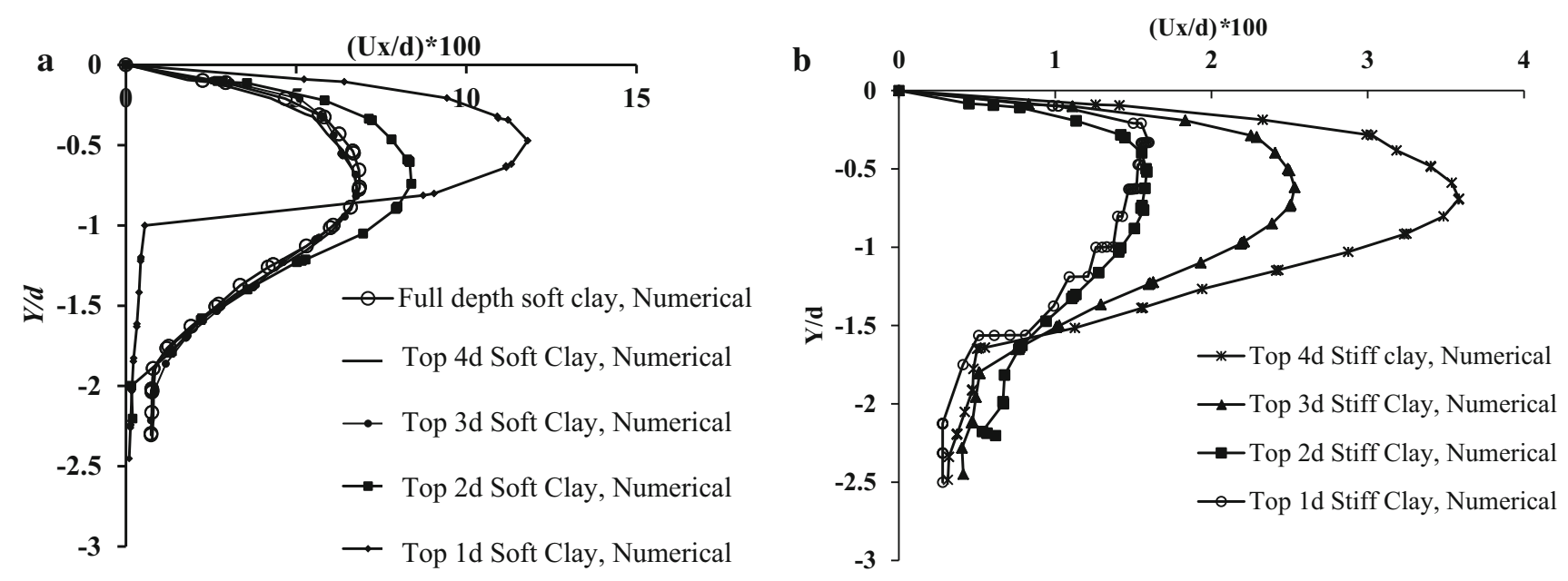

Fig. 12 a Lateral displacement along the length of stone column for stone column area loading $\left(L_{1}\right)$. b Lateral displacement along the length of stone column for stone column area loading $\left(L_{2}\right)$

Fig. 13 Extracted stone columns (column area alone loaded) from $\mathrm{L}$ to $\mathrm{R}$ :

a homogeneous soft clay, b layered soil having $2 \mathrm{D}$ soft clay $\left(L_{1}\right)$, $\mathbf{c}$ layered soil having 1D soft clay $\left(L_{1}\right)$
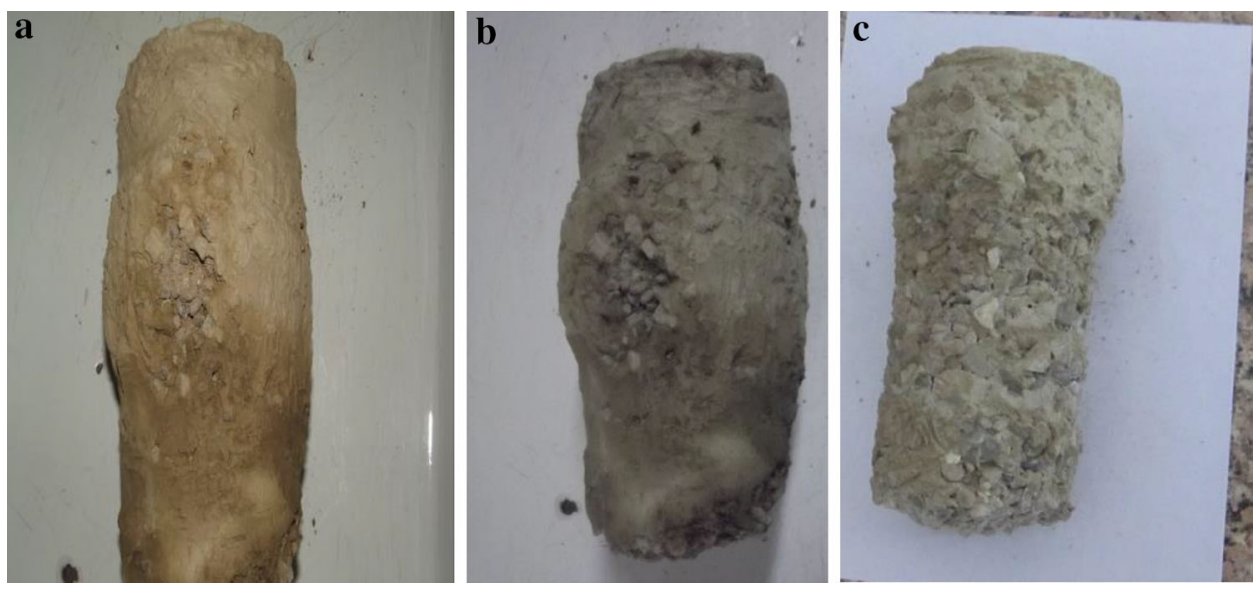


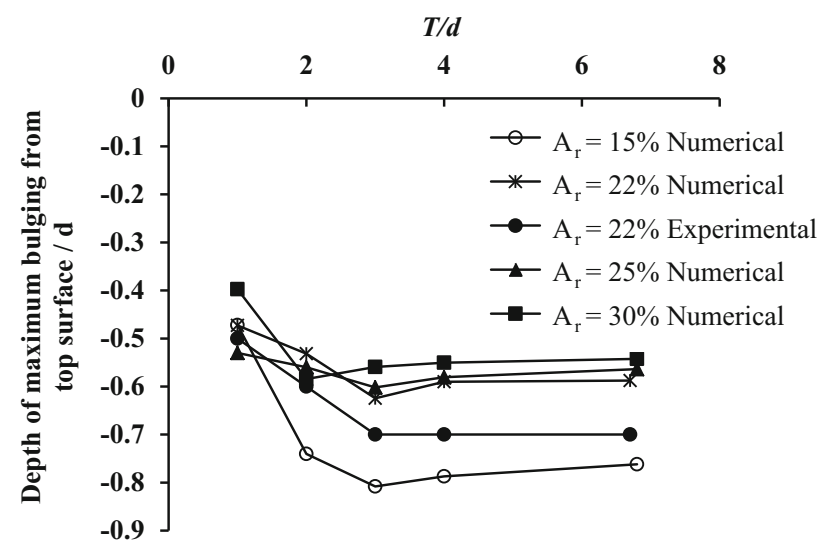

Fig. 14 Change in depth of maximum bulging $\left(L_{1}\right)$

depth of the top soft clay increases, the extent of bulging also increases and remains constant at two times the diameter of the stone column which is also observed from the extracted stone columns after test and shown in Fig. 13. For the top clay layer thickness more than two times the diameter of stone column, the underlying soil layer does not influence the bulging behaviour of the stone column for both the layering systems $L_{1}$ and $L_{2}$ respectively.

The depth of maximum bulging has been plotted for different depths of the top clay thickness in Fig. 14 for the layering system $L_{1}$. It can be observed that there is no significant variation in the depth of maximum bulging for $L_{1}$ layering system. The maximum bulging happens in top $0.5 \mathrm{~d}-0.8 \mathrm{~d}$ portion. The depth of maximum bulging for $1 \mathrm{~d}$ soft clay is at a shallow depth than rest of the layered soils which is also observed from the extracted shape of stone column after test (Fig. 13c). The point of maximum bulging shifts downward for $2 \mathrm{~d}$ and $3 \mathrm{~d}$ depth of top soft clay and beyond which it almost remains constant. The depth of maximum bulging for $A_{\mathrm{r}}=15 \%$ is more when compared with the higher area replacement ratios. This happens as the shear stress near the bulging portion in case of $A_{\mathrm{r}}=15 \%$ is not fully mobilized as in case of higher area replacement ratios. The similar findings were also observed by Wood et al. [40]. They observed that as the area replacement ratio increases, the columns bulge more in the upper zone of the soil layers and subsequently transfer the load to the greater depth.

\section{Conclusions}

The present study investigates the soil layering effects on the performance of the stone column through laboratory model tests and the numerical study. Two types of layering systems, the soft clay overlying stiff clay and vice versa have been taken for the present study. The finite element based software package Plaxis has been used for numerical analysis. The limiting axial stress of the improved ground, limiting axial stress of stone column and the stiffness improvement factor of the treated ground have been investigated for different area replacement ratio and different top soft and stiff clay layer thickness. Following conclusions may be drawn from the observations of the present work.

(i) The behaviour of the stone column in layered soil is significantly different from the homogeneous soil up to a certain thickness of top soil. The behaviour of the improved layered soil and stone column alone depends on the thickness of the top layer and the area replacement ratios of the stone column.

(ii) The limiting axial stress of the entire improved soil is found to be influenced by the top soft soil up to four times the diameter of the stone column and beyond which the thickness of the top soft clay has negligible effects on the limiting axial stress of the treated soil. For stiff clay overlying soft clay, the limiting axial stress of the entire improved soil increases with increase in the thickness of top stiff clay. The limiting axial stress of treated layered soil also increases with the increase in the area replacement ratios.

(iii) From the linear load-displacement relation, the stiffness of the improved soil may be calculated by taking the average slope of the curves. The stiffness improvement factor of the treated layered soil is found to be dependent on the thickness of top soft soil and attains maximum value for the homogenous soft clay. The improvement in stiffness of the improved layered soil increases with increase in the area replacement ratios.

(iv) The stiffness improvement factor of the improved layered soil for stiff clay overlying soft clay increases with increase in the area replacement ratios. The improvement factor is independent of the thickness of the top stiff layer and remains constant for different thickness of the top stiff layer.

(v) The limiting axial stress of the stone column increases with increase in the area replacement ratio. Limiting axial stress decreases with increase in the thickness of the soft clay up to two times the diameter of the stone column. For top soft clay layer thickness is more than two times the diameter of stone column, the effect of bottom stiff layer on the limiting axial stress of stone column diminishes.

(vi) For stiff clay overlying the soft clay, the limiting axial stress of the stone column increases with 
increase in the thickness of top stiff clay up to two times the diameter of the stone column beyond which it remain constant.

(vii) The vertical extent of bulging increases with the increase in the thickness of the top clay layer and remains constant at two times the diameter of the stone column for both the layering systems. For the top clay thickness more than two times the diameter of stone column, the underlying clay layer does not influence the bulging behaviour of the stone column improved ground. The depth of maximum bulging was found to be at a depth of 0.5-0.8 times the diameter of the stone column and is also found to be independent of top soil when its thickness exceeds two times the diameter of the stone column.

\section{References}

1. Alamgir M, Miura N, Pooorooshasb Madhav MR (1996) Deformation analysis of soft ground reinforced by columnar inclusions. Comput Geotech 18(4):267-290

2. Ambily AP, Gandhi SR (2007) Behavior of stone columns based on experimental and FEM analysis. J Geotech Geoenviron Eng (ASCE) 133(4):405-441

3. Barksdale RD, Bachus RC (1983) Design and construction of stone columns, vol 1, Report no. FHWA/RD 83/026, National technical Information Service, Springfield, Virginia

4. Baumann V, Bauer GEA (1974) The performance of foundations on various soils stabilized by the vibro-compaction method. Can Geotech J 11(4):509-530

5. Bergado DT, Asakami H, Alfaro MC, Balasubramaniam AS (1991) Smear effects of vertical drains on soft Bangkok clay. J Geotech Eng Div (ASCE) 117(10):1509-1529

6. Black JA, Sivakumar V, Bell A (2011) The settlement performance of stone column foundations. Geotechnique 61(11):909-922

7. Bowles JE (1997) Foundation analysis and design. Mc Graw Hill International Editions, Singapore

8. Castro J, Sagaseta C (2009) Consolidation around stone columns. Influence of column deformation. Int J Numer Anal Methods Geomech 33:851-877

9. Choobbasti AJ, Zamatkesh A, Noorzad R (2011) Performance of stone columns in soft clay: numerical evaluation. Geotech Geol Eng 29(5):675-684

10. Elshazly HA, Hafez DA, Mossaad ME (2008) Reliability of conventional settlement evaluation for circular foundations on stone columns. Geotech Geol Eng 26(3):323-334

11. Greenwood DA (1970) Mechanical improvement of soils below ground surfaces. In: Proceedings of the ground engineering conference, Institution of Civil Engineers, London, pp 11-22

12. Guetif Z, Bouassida M, Debats JM (2007) Improved clay characteristics due to stone column installation. Comput Geotech 34:104-111

13. Hughes JMO, Withers NJ (1974) Reinforcing of soft cohesive soils with stone columns. Ground Eng 7(3):42-49

14. IS: 15284 (Part 1) (2003) Indian standard code of practice for design and construction for ground improvement-guidelines. Indian Standards Institution, New Delhi, India

15. IS: 2720 (Part 4) (1995) Method of test for soils: Grain size analysis. Indian Standards Institution, New Delhi, India
16. IS: 2720 (Part 5) (1995) Method of test for soils: determination of liquid and plastic limit. New Delhi, India

17. IS: 2720 (Part 7) (1995) Method of test for soils: determination of water content-dry density relation using light compaction. Indian Standards Institution, New Delhi, India

18. IS: 2720 (Part 10) (1995) Method of test for soils: unconfined compressive strength. Indian Standards Institution, New Delhi, India

19. IS: 2720 (Part 3) (1980) Methods for test for soil, determination of specific gravity of fine grained soil. Indian Standards Institution, New Delhi, India

20. IS: 2720 (Part 15) (1980) Methods for test for soil, determination of consolidation properties. Indian Standards Institution, New Delhi, India

21. IS: 2720 (Part 13) (1986) Methods for test for soil, direct shear test. Indian Standards Institution, New Delhi, India

22. Killeen (2012) Numerical modelling of small groups of stone columns. PhD thesis, National University of Ireland Galway

23. Madhav MR, Vitkar PP (1978) Strip footing on weak clay stabilized with a granular trench or pile. Can Geotech J 15(4):605-609

24. Madhav MR, Iyenger NGR, Vitkar RP, Nandia A (1979) Increased bearing capacity and reduced settlements due to inclusions in soil. Proc Int Conf Soil Reinf 2:239-333

25. McCabe BA, Nimmons GJ, Egan D (2009) A review of field performance of stone columns in soft soils. Proc Inst Civ Eng Geotech Eng 162(6):323-334

26. McKelvey D, Sivakumar V, Bell A, Graham J (2004) Modeling vibrated stone columns in soft clay. Proc Inst Civ Eng Geotech Eng 157(3): 137-149

27. Mitchell JK, Huber TR (1985) Performance of a stone column foundation. J Geotech Eng Div (ASCE) 111(2):205-223

28. Mitra S, Chattopadhyay BC (1999) Stone columns and design limitations. In: Proceedings of Indian Geotechnical Conference, India, pp 201-205

29. Munfakh GA, Sarkar S K, Castelli RP(1983) Performance of a test embankment founded on stone columns. In: Proceedings of International Conference on Advances in Piling and Ground Treatment for Foundations, London, pp 259-265

30. Priebe HJ (1995) The design of vibro replacement. Ground Eng 28(12):31-37

31. Pulko B, Majes B (2006) Analytical method for the analysis of stone-columns according to the Rowe dilatancy theory. Acta Geotech Slov 3(1):37-45

32. Pulko B, Majes B, Logar J (2011) Geosynthetic-encased stone columns: analytical calculation model. Geotext Geomembr 29:29-39

33. Ranjan G, Rao ASR (2010) Basic and applied soil mechanics. New Age International Publishers, New Delhi

34. Saha S, Santhanu S, Roy A (2000) Analysis of stone column in soft ground. In: Proceedings Indian Geotechnical Conference, Bombay, India, pp 297-300

35. Sexton BG, McCabe BA, Castro J (2013) Appraising stone column settlement prediction methods using finite element analysis. DOI, Acta Geotech. doi:10.1007/s11440-013-0260-5

36. Shahu JT, Reddy YR (2011) Clayey soil reinforced with stone column group: model tests and analyses. J Geotech Geoenviron Eng (ASCE) 137(12):1265-1274

37. Shivashankar R, Dheerendra Babu MR, Nayak S, Rajathkumar V (2011) Experimental studies on behaviour of stone columns in layered soils. Geotech Geol Eng 29(4):749-757

38. Sivakumar V, Jeludine DKNM, Bell A, Glynn DT, Mackinnon P (2011) The pressure distribution along the stone column in soft clay under consolidation and foundation loading. Geotechnique 61(7):613-620 
39. Vesic AS (1972) Expansion of cavities in infinite soil mass. J Soil Mech Found Div ASCE 98(3):265-290

40. Wood DM, Hu W, Nash DFT (2000) Group effects in stone column foundations: model tests. Geotechnique 50(6):689-698
41. Yan J, Ye SL (2001) Simplified method for consolidation rate of stone column reinforced foundations. J Geotech Geoenviron Eng (ASCE) 127(7):597-603 